\title{
Relationship Between Shared Leadership Style and Job Satisfaction of Secondary School Teachers
}

\author{
Saghir Ahmad \\ PhD Scholar, Institute of Education and Research, University of the Punjab, Lahore Pakistan \\ Dr. Ayesha Batool \\ Assistant Professor, The Department of Education, Lahore College for Women University, Lahore Pakistan
}

\begin{abstract}
Teaching is a highly noble profession and teachers are always a strong pillar to the society. The ultimate process of education could be simplified as a meaningful interaction between the teacher and the learner. The teacher thus plays a direct and crucial role in molding a pupil towards education. The present study aimed to explore the relationship between shared leadership style and teachers' job satisfaction in secondary schools. To achieve this purpose, a correlation research method was used. The population of the study included all the secondary school teachers in the Lahore district. The sample consisted of 200 secondary school teachers. The self-developed questionnaire related school shared leadership style and job satisfaction was used for data collection in this study. The data were analyzed by using descriptive and inferential statistical techniques. It was concluded that there was positive weak significant relationship between shared leadership and teachers' job satisfaction. On the basis of findings, school leadership may improve the shared leadership for the enhancement of the teacher's job satisfaction. Head of the school may develop and promote positive and warmth relationship with teachers.
\end{abstract}

Keywords: Shared leadership, job satisfaction, and school teachers.

DOI: $10.7176 /$ RHSS/9-11-01

Publication date:June $30^{\text {th }} 2019$

\section{Introduction}

Leadership is the ability of an individual or a group of personnel to impact and guide followers and staff members in the organization. It is not about management functions, it's all about to motivate and entice individuals towards goals achievements. Management has subordinates as well as leader has followers. They follow the leader in all aspects. They just wait signal of leader and perform the tasks effectively (Oakes, 2006). There are different types of leadership which are applicable to run the organizations especially academic institutions. Shared leadership is also one of the emerging and new style to lead the institutions. It is a social phenomenon including common goals between colleagues as they work in the direction of group goals. The ability of leadership impact others and happens with regards to colleague connections and presumes the presence of workers (Bedeian \& Hunt, 2006). This perspective of shared authority has been generally applicable and suitable in academic world.

The idea of teacher leadership has turned out to be progressively inserted in the language and practice of educational development. The focal precept of educator leadership lines up with thoughts of individual strengthening and restriction of the executives that have stretched out since the commencement of the United States (Carson, Tesluk, \& Marrone, 2007). In particular, the idea of instructive leadership recommends that instructors appropriately and critically hold a focal position in the manners in which schools work and in the center elements of educating and learning. In spite of the fact that this is certifiably not another idea, "what's happening are expanded acknowledgment of instructor authority, dreams of extended educator positions of leadership, and new hope in the commitments these extended jobs may make in improving schools" (Smylie \& Denny, 1990, p. 237).

There are numerous measurements, parts, and variables which influence shared leadership in common purpose, social help, group condition, relational aptitudes, cognitive approach, and enthusiastic knowledge. Leadership is encouraged by a group condition that comprises of three elements, shared goal and objectives, supportive condition, and shared decision making. Satisfaction at workstation focuses to a standout amongst the most unpredictable zones confronting today administrators. The idea of job satisfaction alludes to the frame of mind and emotions which individuals have at work. Positive and humble behavior towards work show job pleasure. Negative and troublesome attitude towards work demonstrate work disappointment (Armstrong, 2006).

Teaching is an exceptionally honorable profession and instructors are considered the backbone of any nation. A definitive process of education could be streamlined as an important collaboration between the instructor and the student. The educator in this way plays an immediate and critical role in modeling a student towards education. Hakanen, Bakker, and Schaufeli (2006) utilized the Job Demands Resources Model as the premise of the suggestion that there are two parallel procedures associated with job related prosperity among instructors, specifically a vigorously procedure (for example need of job, burnout, sick wellbeing) and an 
inspirational procedure (employment assets, commitment, hierarchy).

Day, Gronn, and Salas (2004) pointed out group results that radiate from shared leadership. Besides, Bligh, Pearce, and Kohles (2006) confirmed, mutual leadership in this manner offers an idea of administration practice as a group level factor where practices are sanctioned by different people instead of exclusively by those at the top or by those in formal influential positions. To abridge, a survey of the writing uncovers shared authority as a social, community oriented administration procedure or wonder including groups or gatherings that commonly impact each other. The term shared leadership is utilized itself for example, participatory leadership, cooperative leadership, shared and consultative leadership, and various varieties of these key terms (Grasmick, Davies, \& Harbor, 2012). The term mutual leadership is used to capture the aim as a collective idea.

\section{Significance of Study}

The perceptions of teachers about shared leadership, and the resultant effect on job satisfaction, is important to understand. The findings of study have significant importance for the school administrators who believe on shared leadership. In this leadership, head of the institution share things and ideas with followers and colleagues. Leaders involve personnel in decision making process and behave friendly with them. The results of study are helpful to understand the association between mutual leadership and job satisfaction of teachers. Leadership affects also personnel work satisfaction level. The findings may provide understanding regarding shared leadership and work satisfaction in teaching profession. This study has number of implication to manage shared leadership among school head and school teachers in Lahore. Due to advancement in technology and high competition there is a race among institutes. This study shows that if the school environment is supportive and cooperating then teachers get job satisfaction.

\section{Research Objectives}

The following were the objectives of the study to:

1. Explore the relationship between shared leadership style of heads and job satisfaction of teachers.

2. Identify the difference in teachers' perceptions regarding shared leadership style of heads and job satisfaction of faculty on the basis of their demographic variables.

\section{Research Methodology}

In this study correlation research design was used. The study was descriptive and survey type in nature. The population of this study included the government and private secondary school teachers of Lahore district. The Population for this study consisted of secondary school teachers of Lahore. Convenient sampling technique was used to select sample from population. The data were collected from 200 school teachers. One hundred teachers selected from public and one hundred from private secondary schools. The instrumentation used for the study was developed by the researcher. The opinion of experts was taken for the validation of questionnaire before finalizing it. Questionnaire was developed regarding shared leadership and job satisfaction. There were 30 statements on shared leadership and job satisfaction. All statements designed at five-point Likert scales. Strongly Disagree, Disagree, Neutral, Agree and Strongly Agree. The reliability of the instrument was ensured by applying Cronbach Alpha. The value of internal consistency was 0.921, which is statistical significant. The researchers visited the school personally for data collection. Descriptive and inferential statistical techniques were used to analyze data. Pearson $r$ was used for relationship between shared leadership and job satisfaction. Independent sample t-test and one way ANOVA were used to check demographic difference in teachers' perceptions regarding shared leadership of school heads and teacher's job satisfaction.

\section{Data Analysis}

The detail of data analysis is given below.

Table 1

Mean and Standard Deviation of Shared Leadership and Job Satisfaction

\begin{tabular}{lccc}
\hline Variables & $\mathrm{N}$ & Mean & SD \\
\hline shared leadership & 200 & 56.99 & 6.911 \\
Job Satisfaction & 200 & 66.56 & 5.095 \\
\hline
\end{tabular}

Table shows mean and standard deviation values of shared leadership $(M=56.99, S D=6.911)$ and job satisfaction $(M=66.56, S D=5.095)$. 
Table 2

Relationship between Shared Leadership and Job Satisfaction

\begin{tabular}{llcc}
\hline Variables & & Shared leadership & Job Satisfaction \\
\hline Shared Leadership & Pearson Correlation & 1 & .269 \\
& Sig. (2-tailed) & & .000 \\
& N & 200 & 200 \\
Job Satisfaction & Pearson Correlation & .269 & 1 \\
& Sig. (2-tailed) & .000 & 200 \\
\hline
\end{tabular}

Table indicates the result of Pearson $r$, which was applied to explore the correlation between shared leadership and job satisfaction of teachers. There was weak positive relationship $r=.269$ between two variables (leadership and work satisfaction). School principals need to adopt shared leadership style to run the institutions and involve staff members in different activities.

Table 3

Difference between Perceptions of Public and Private School Teacher regarding Leadership and Job Satisfaction

\begin{tabular}{lllcccr}
\hline Variables & School & $t$-value & Mean & $S D$ & $d f$ & Sig \\
\hline Shared Leadership & Public & -2.031 & 56.01 & 6.634 & 198 & .044 \\
& Private & & 57.98 & 7.075 & & \\
Job Satisfaction & Public & -1.363 & 66.07 & 5.166 & 198 & .174 \\
& Private & & 67.05 & 5.001 & & \\
\hline
\end{tabular}

Independent sample t-test used to make the difference between private and public school teachers' perceptions regarding the head teacher shared leadership and job satisfaction in schools. There is significant difference in shared leadership scores between public $(M=56.01, S D=6.634)$ and for private school teachers; $M=57.98, S D=7.075, t(-2.031)=198, p=.044$. There is no significant difference in job satisfaction scores between public $(M=66.07, S D=5.166)$ and for private school teachers; $M=67.05, S D=5.001, t(-1.363)=198$, $p=.174$. It is concluded that public and private school teachers have difference in their opinions regarding shared leadership but they have no difference about job satisfaction.

Table 4

One Way ANOVA to check Difference about Shared Leadership and Job Satisfaction on the Basis of Teachers' Qualification

\begin{tabular}{|c|c|c|c|c|c|c|}
\hline Variables & & Sum of Squares & $d f$ & Mean Square & $F$ & Sig. \\
\hline \multirow[t]{3}{*}{ Shared leadership } & Between Groups & 639.278 & 3 & 213.093 & 4.710 & .003 \\
\hline & Within Groups & 8867.717 & 196 & 45.243 & & \\
\hline & Total & 9506.995 & 199 & & & \\
\hline \multirow[t]{3}{*}{ Job satisfaction } & Between Groups & 308.621 & 3 & 102.874 & 4.150 & .007 \\
\hline & Within Groups & 4858.659 & 196 & 24.789 & & \\
\hline & Total & 5167.280 & 199 & & & \\
\hline
\end{tabular}

Table shows that one-way ANOVA was applied to know the difference in mean scores of shared leadership and job satisfaction of teachers on the basis of their qualification difference. Results show that there was significant difference in mean scores of leadership $F(3,196)=4.710$ at $p=.003$; and job satisfaction $F(3,196)=$ 4.150 at $p=.007$. It is concluded that teachers have difference in mean scores regarding shared leadership and job satisfaction due to qualification difference.

Table 5

One Way ANOVA to check Difference about Shared Leadership and Job Satisfaction on the Basis of Teachers' Job Experience

\begin{tabular}{|c|c|c|c|c|c|c|}
\hline Variables & & Sum of Squares & $d f$ & Mean Square & $F$ & Sig. \\
\hline \multirow[t]{3}{*}{ Shared Leadership } & Between Groups & 425.947 & 3 & 141.98 & 3.064 & .099 \\
\hline & Within Groups & 9081.048 & 196 & 46.33 & & \\
\hline & Total & 9506.995 & 199 & & & \\
\hline \multirow[t]{3}{*}{ Job Satisfaction } & Between Groups & 355.596 & 3 & 118.53 & 4.828 & .343 \\
\hline & Within Groups & 4811.684 & 196 & 24.54 & & \\
\hline & Total & 5167.280 & 199 & & & \\
\hline
\end{tabular}

Table shows that one-way ANOVA was applied to know the difference in mean scores of shared leadership and job satisfaction of teachers on the basis of their job experience. Results show that there was no significant difference in mean scores of leadership $F(3,196)=3.064$ at $p=.099$; and job satisfaction $F(3,196)=4.828$ at $p$ $=.343$. It is concluded that teachers have no difference in mean scores regarding shared leadership and job satisfaction due to job experience difference. 


\section{Conclusion}

Teaching is an exceptionally honorable profession and instructors are considered the backbone of any nation. A definitive process of education could be streamlined as an important collaboration between the instructor and the student. The educator in this way plays an immediate and critical role in modeling a student towards education when they have positive and shared leadership. Positive leaders give motivation and entice faculty members towards goals accomplishments. The intention of researchers to conduct this study was to explore correlation between shared leadership and teachers' job satisfaction. The study was correlation and survey type in nature. Secondary schools teachers were participated as research participants in this study. It is concluded that there is weak positive correlation between shared leadership of school head and their teachers' job satisfaction. It was observed that those schools head teachers adopt mutual leadership style their teachers are more satisfied with their jobs. Thus, if head of the schools have sharing leadership then the level of teachers' job satisfaction may increase. It is concluded that public and private school teachers have difference in their opinions regarding shared leadership but they have no difference about job satisfaction. It is also confirmed that teachers have difference in mean scores regarding shared leadership and job satisfaction due to qualification difference.

\section{Recommendations}

In Pakistan institutes need to set rules and regulation for time management, policies for compensation, training of managing work related tasks and providing a supportive environment to increase job satisfaction of school teachers. Following are the recommendations for future.

1. School education department may promote shared leadership at school level.

2. Head of school teachers may be adopt positive attitude toward their school teachers.

3. School education department may increase the compensation of the teachers set better perform.

4. Teachers may be facilitated by the school head.

5. Teachers may build strong relationship with each other's for creating good environment in school.

\section{References}

Armstrong, M. (2006). A handbook of human resource management practice (10th ed.). London, Kogan Page Publishing.

Bedeian, A. G., \& Hunt, J. G. (2006). Academic amnesia and vestigial assumptions of our forefathers. The Leadership Quarterly, V17, 190-205.

Bligh, M. C., Pearce, C. L., \& Kohles, J. C. (2006). The importance of self and shared leadership in team based knowledge work: A meso-level model of leadership dynamics. Journal of Managerial Psychology, 21(4), 296-318.

Carson, J. B., Tesluk, P. E., \& Marrone, J. A. (2007). Shared leadership in teams: An investigation of antecedent conditions and performance. Academy of Management Journal, 50(5), 1217-1234.

Day, D. V., Gronn, P., \& Salas, E. (2004). Leadership capacity in teams. The Leadership Quarterly, 15(6), 857880.

Einar-M, S., \& Sidsel, S. (2007). Dimensions of teacher self-efficacy and relations with strain factors, perceived collective teacher efficacy, and teacher burnout. Journal of Educational Psychology, 99(3), 611-625.

Grasmick, Davies, \& Harbour, (2012). Organizational culture and leadership in education. Journal of Education Sciences, 1(2), 15-31.

Hakanen, J. J., Bakker, A. B., \& Schaufeli, W. B. (2006). Burnout and work engagement among teachers. Journal of School Psychology, 43(6), 495-513.

Henson, R. K. (2001). Teacher self-efficacy: Substantive implications and measurement dilemmas. Presented at the annual meeting of the Educational, Texas A \& M University.

Hiller, N. J., Day, D. V., \& Vance, R. J. (2006). Collective enactment of leadership roles and team effectiveness: A field study. The Leadership Quarterly, 17(4), 387-397.

Menon, M. E., \& Saitis, C. (2006). Satisfaction of pre-service and in-service teachers with primary school organization: Evidence from Greece. Educational Management Administration \& Leadership, 34(3), 345363.

Nil, A. E., \& Kranot, N. (2006). School principal's leadership style and teachers' self-efficacy. Planning and Changing, 37(3-4), 205-218.

Oakes, A. S. (2006). Teachers' Perception of the shared leadership in Ekwusigo Local Government of Anambra State, Nigeria. An International Multidisciplinary Journal, Ethiopia, 7(4), 225-237.

Sally, D. (2002). Co-leadership: Lessons from Republican Rome. California Management Review, 44(4), 84-99. 